\title{
Characteristics of carbon aerogel at variation in pyrolysis conditions
}

- Le Khac Duyen

- Pham Quoc Nghiep

- Le Anh Kien

Institute for Tropicalisation and Environment, ITE, Ho Chi Minh City, Vietnam

(Manuscript Received on July, 2016, Manuscript Revised on September, 2016)

\begin{abstract}
Carbon aerogel was obtained by pyrolysis of organic aerogel by ambient pressure drying technique. The effect of pyrolysis conditions on characteristics of carbon aerogel such as density, specific surface area and conductivity was studied. The properties and structure of carbon aerogel samples were investigated by nitrogen adsorption, four-point probe method and XRD diffraction. The results showed that

carbon aerogel had structure between amorphous and graphite state. The highest specific surface area was $800 \mathrm{~m} 2 / \mathrm{g}$ at pyrolysis temperature of $700^{\circ} \mathrm{C}$. The pore-size was distributed in microporous, with the maximum total pore volume of $0.44 \mathrm{~cm} 3 / \mathrm{g}$. The electrical conductivity of carbon aerogel was highest at pyrolysis temperature of $800-900^{\circ} \mathrm{C}$ with the value in the range of $1.744-1.923 \mathrm{~S} / \mathrm{cm}$
\end{abstract}

Keywords: Aerogel, carbon aerogel, pyrolysis, porous materials, microstructure.

\section{INTRODUCTION}

Carbon aerogels were very interesting monolithic materials with a large of potential applications because of their versatile properties, such as low density, high surface area, high porosity, low electrical resistivity and controllable structure characteristics [1, 2]. Carbon aerogels had been prepared from the different organic aerogel sources in many previous studies. Al-Muhtaseb and Ritter [3] synthesized carbon aerogel from resorcinolformaldehyde organic aerogel at different drying conditions. The experiments data showed that properties of carbon aerogel were affected of many factors such as the catalyst concentration, the initial gel $\mathrm{pH}$, the concentration of solids in the sol, the drying method and the conditions of pyrolysis and activation. Carbon aerogel was synthesized from resorcinol-furfural based organic aerogels in the study of Rejitha et al. [4]. Carbon aerogels obtained by using different catalysts showed BET surface area, average pore size, total pore volumes in the range of $438-496 \mathrm{~m}^{2} / \mathrm{g}, 17.9-22.4 \AA$ and $0.20-0.27 \mathrm{~cm}^{3} / \mathrm{g}$, respectively. Moreover, carbon aerogel was synthesized from polyureas, melamineformaldehyde and polyurethanes. Among these materials, the resorcinol-formaldehyde system was the most frequently studied and the reaction parameters were the most well understood [5].

Carbon aerogel are prepared by the polycondensation of resorcinol (R) with 
formaldehyde (F) under sodium carbonate as base catalyst and pyrolysis process. Generally, there were four steps in the preparation of carbon aerogels, namely sol-gel formation, solvent exchange, drying and pyrolysis, all of which affect the characteristics of carbon aerogels. The most important step that was influence on the properties of carbon aerogel was the drying procedure. The conventional drying method involved a supercritical drying, which was very complex, expensive and dangerous. To overcome these disadvantages, new preparation methods for producing carbon aerogels under ambient pressure drying conditions have been suggested [6-8]. According to these methods, organic aerogel could be drying at ambient pressure with minimize volume shrinkage.

In previous study [9], carbon aerogel was synthesized from resorcinol-formaldehyde via ambient pressure drying method. The purpose of this paper was to further research the influence of pyrolysis conditions on properties of carbon aerogel. The properties of carbon aerogel such as specific surface area, pore-size distribution were investigated by nitrogen adsorption measurements. The electrical conductivity of these samples was evaluated by four-point probe method. In addition, the structure of carbon aerogel was characterized by XRD diffraction.

\section{EXPERIMENTAL}

\subsection{Preparation of carbon aerogel}

Carbon aerogel (CA) was derived from pyrolysis of a resorcinol-formaldehyde (RF) aerogel. The molar ratio of formaldehyde (F) to resorcinol (R) was held at a constant value of 2 . They were dissolved in distilled water with $\mathrm{Na}_{2} \mathrm{CO}_{3}$ as a base catalyst, the mass percentage of the reactants in solution was set at $\mathrm{RF}=40 \%$, and the molar ratio of resorcinol to catalyst (C) was set at $\mathrm{R} / \mathrm{C}=1000$. Sol-gel polymerization of the mixture was carried out in plastic moulds by holding the mixture at room temperature for $24 \mathrm{~h}$, at $50^{\circ} \mathrm{C}$ for $24 \mathrm{~h}$, and at $80^{\circ} \mathrm{C}$ for $72 \mathrm{~h}$ to obtain RF wet gels. The aqueous gels were then exchanged with acetone for 3 days. Subsequently, RF organic aerogels were prepared by directly drying RF wet gels at ambient temperature and pressure for 5 days. Carbon aerogels were obtained via pyrolyzing $\mathrm{RF}$ organic aerogels at $800^{\circ} \mathrm{C}$ in a continuous nitrogen atmosphere, flowing at a rate of 400 $\mathrm{mL} / \mathrm{min}$ for $3 \mathrm{~h}$ and then in a flow of $\mathrm{CO}_{2}$ for 2 $\mathrm{h}$, flow rate of $200 \mathrm{~mL} / \mathrm{min}$.

\subsection{Characterization methods}

Surface area and pore-size distribution of carbon aerogels samples were characterized by analysis of nitrogen absorption-desorption isotherms measured by ASAP 2020 analyzer (Micrometrics Instruments Corp.). BrunauerEmmett-Teller (BET) method was used for total surface area measurements, and $\mathrm{t}-$ plot method was used for estimating mesopore surface area. Pore-size distribution was obtained by the Barret-Joyner-Halenda (BJH) method from desorption branch of the isotherms. Total porevolume was calculated from the adsorbed volume of nitrogen at $\mathrm{P} / \mathrm{P}_{0}=0.99$ (saturation pressure). The bulk densities of the samples were estimated by measuring the dimensions and the mass of each monolithic sample. Electrical conductivities of carbon aerogel have been determined by using four-point probe method. Structure of carbon aerogel was characterized $\mathrm{X}$-ray diffraction using a Bruker D8 Advance diffractometer with $\mathrm{Cu}-\mathrm{K} \alpha$ radiation $(\lambda=1.54060 \AA)$ operated at the voltage 
and current values of $40 \mathrm{kV}$ and $40 \mathrm{~mA}$ respectively for the $2 \theta$ values in the range $5-70^{\circ}$ at a scan speed of $1.2 \% \mathrm{~min}$.

\section{RESULTS AND DISCUSSION}

\subsection{Effect of pyrolysis conditions on properties of carbon aerogel}

During pyrolysis, the RF aerogel structure was transformed into a relatively pure carbon structure by removing any remaining oxide and hydrogen groups at an elevated temperature.
Variations in the pyrolysis conditions caused significant changes in the properties of the carbon aerogel. A summary of these changes was shown in Table 1. Figure 1 showed the changes in mass loss and shrinkage of RFderived carbon aerogel via pyrolysis. Higher pyrolysis temperature tended to increase the mass loss of carbon aerogel. The mass loss was in the range of $49-63 \%$. The shrinkage of the samples was almost constant at $\sim 50 \%$ during increase the pyrolysis temperature from 600 to $900^{\circ} \mathrm{C}$.

Table 1. Characteristics of carbon aerogel at different pyrolysis temperature.

\begin{tabular}{|c|c|c|c|c|c|}
\hline $\begin{array}{c}\text { Temperature } \\
\left({ }^{\circ} \mathrm{C}\right)\end{array}$ & $\begin{array}{c}\text { Mass } \\
\text { loss } \\
\Delta \mathrm{m}(\%)\end{array}$ & $\begin{array}{c}\text { Shrinkage } \\
\Delta \mathrm{V}(\%)\end{array}$ & $\begin{array}{c}\text { Density } \\
\left(\mathrm{g} / \mathrm{cm}^{3}\right)\end{array}$ & $\begin{array}{c}\text { Electrical } \\
\text { conductivity } \\
(\mathrm{S} / \mathrm{cm})\end{array}$ & $\begin{array}{c}\text { Specific surface } \\
\text { area } \\
\left(\mathrm{m}^{2} / \mathrm{g}\right)\end{array}$ \\
\hline 600 & 49.0 & 49.2 & $0.441-0.489$ & 0.000 & 467.15 \\
\hline 700 & 52.6 & 50.6 & $0.543-0.636$ & $0.021-0.241$ & 800.83 \\
\hline 800 & 56.1 & 48.6 & $0.364-0.567$ & $0.800-1.923$ & 779.06 \\
\hline 900 & 62.9 & 52.9 & $0.430-0.525$ & $0.758-1.744$ & 698.34 \\
\hline
\end{tabular}

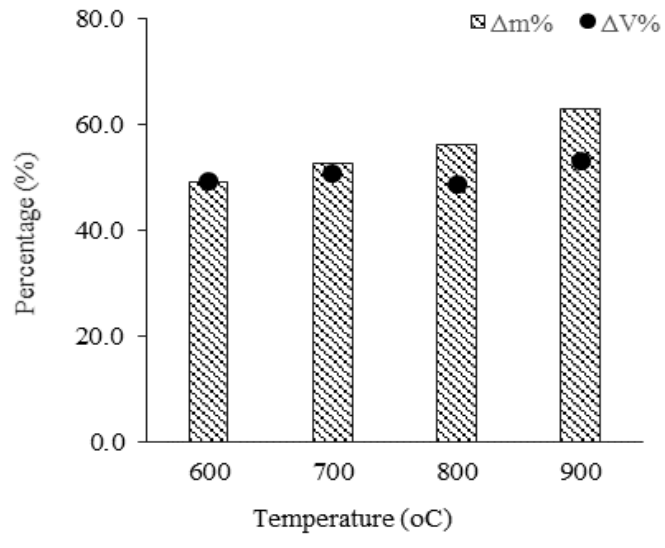

Figure 1. Mass loss and shrinkage of RF-derived carbon aerogel.

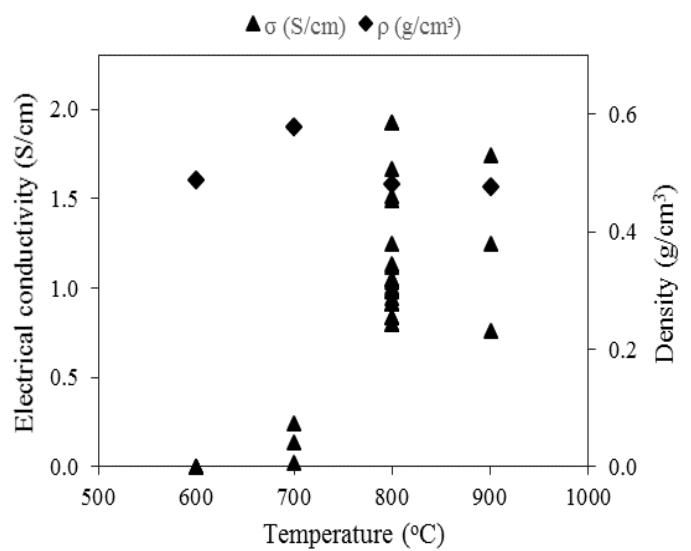

Figure 2. Effect of pyrolysis temperature on electrical conductivity and density of carbon aerogel 
The electrical conductivity and specific surface area were also affected by pyrolysis temperature. It was found that when the pyrolysis temperature was increases from 600 to $800^{\circ} \mathrm{C}$, the electrical conductivity of carbon aerogel increased from 0 to $1.923 \mathrm{~S} / \mathrm{cm}$ and then went down to $1.744 \mathrm{~S} / \mathrm{cm}$ with rising pyrolysis temperature to $900^{\circ} \mathrm{C}$ (Figure 2). The electrical conductivity of carbon aerogel depended on concentration of graphite and electrochemical double-layer capacitance existence in its structure. The temperature required for complete graphitization of RF aerogel may exceed $2000^{\circ} \mathrm{C}$, when aerogel pyrolyzed at $800^{\circ} \mathrm{C}$ contain district graphite structure [3]. Meanwhile, the electrochemical double-layer capacitance exhibited a maximum between 800 and $900^{\circ} \mathrm{C}$ [10]. Thus, the electrical conductivity of carbon aerogel increased with increasing pyrolysis temperature to $800^{\circ} \mathrm{C}$. However, the specific surface area of the samples was decreased slightly with increasing pyrolysis temperature above $700^{\circ} \mathrm{C}$, whereas the specific surface area increases with increasing pyrolysis temperature when the latter was under $700^{\circ} \mathrm{C}$ (Figure 3). The specific surface area of carbon aerogel reached 467, 800, 779 and $698 \mathrm{~m}^{2} / \mathrm{g}$ at the pyrolysis temperature of $600,700,800$ and $900^{\circ} \mathrm{C}$, respectively.

Other parameter was influence on properties of carbon aerogel was pyrolysis and activation time. The effect of pyrolysis time was investigated at pyrolysis temperature of $800^{\circ} \mathrm{C}$ condition. Figure 4 showed the effect of pyrolysis time on electrical conductivity and density of the carbon aerogel samples. It was found that when the pyrolysis time increased up to $3 \mathrm{~h}$, the conductivity of carbon aerogel increased.

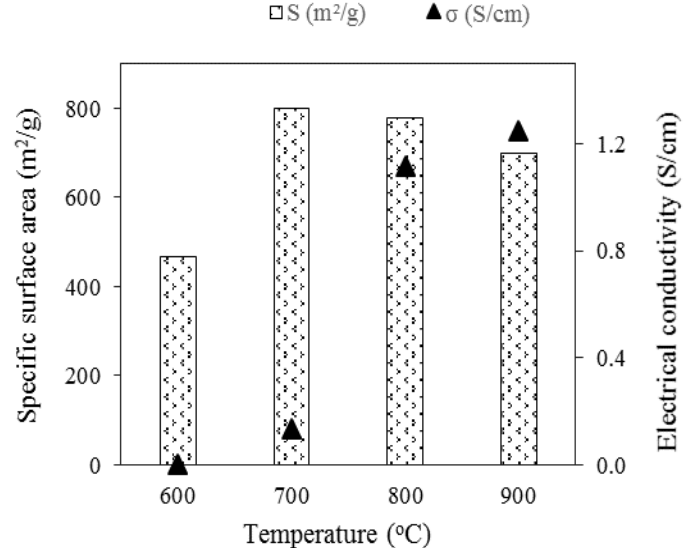

Figure 3. Specific surface area and electrical conductivity of carbon aerogel at different pyrolysis temperature.

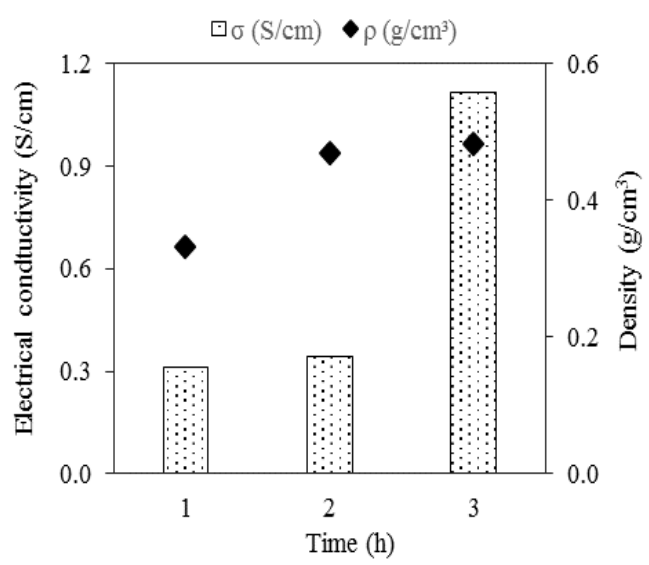

Figure 4. Electrical conductivity and density of carbon aerogel at variation of pyrolysis time.

The density of the samples was slightly increased with rising pyrolysis time because of density of graphite $\left(2.09-2.23 \mathrm{~g} / \mathrm{cm}^{3}\right)$ in structure of carbon aerogel. The higher pyrolysis time, the more graphitic structure obtained and it was the reason of increasing density of carbon aerogel. Moreover, activation time was also influence on electrical conductivity of carbon aerogel. According to the research of Al-Muhtaseb and Ritter [3], the electrochemical capacitance of carbon aerogel samples was 
increased with increasing the thermal activation time up to $\sim 3 \mathrm{~h}$ and thereafter reduced it. The electrochemical double-layer capacitance of RF carbon aerogel was maximum after $\sim 3 \mathrm{~h}$ of activation with $\mathrm{CO}_{2}$ [11]. Thus, the electrical conductivity of carbon aerogel increased with increasing the activation time up to $\sim 3 \mathrm{~h}$.

\subsection{Characteristics of carbon aerogel at variations pyrolysis conditions}

The pore structure of carbon aerogel samples was investigated by nitrogen adsorption $\begin{array}{lllll}\text { measurements at } & 77 & \mathrm{~K} & \text { The }\end{array}$ adsorption/desorption isotherms of carbon aerogels pyrolyzed at 600,800 and $900^{\circ} \mathrm{C}$, showed in Figure 5a, belong to Type IIa in IUPAC classification [12]. This type of isotherms was identified with multilayer absorption on the surface of carbon aerogel, and was characteristic of nonporous or macroporous absorbents. The isotherms exhibit a narrow hysteresis loop, which is typical of thermodynamically irreversible adsorption processes [13]. Figure 5b showed typical poresize distributions of carbon aerogel at various pyrolysis temperature. It was indicated that the pore-size distribution of all carbon aerogel samples were similar. The pore-size of these samples was distributed in the range of 7-9 $\AA$ and 11-30 $\AA$, with average pore-size was $18-22$ A. According to nitrogen absorption measurements, properties of carbon aerogel were calculated and summarized in Table 2. The highest specific surface area of carbon aerogel reached $800 \mathrm{~m}^{2} / \mathrm{g}$ at pyrolysis temperature of $700^{\circ} \mathrm{C}$. The obtained carbon aerogel was contained micro-, meso- and macroporous with the percentage of 58-72, 11-23 and 15-20\%, respectively. The carbon aerogel particle was in the range from 77 to $128 \AA$. The total pore volumes of samples were in the range of 0.18 to $0.44 \mathrm{~cm}^{3} / \mathrm{g}$.

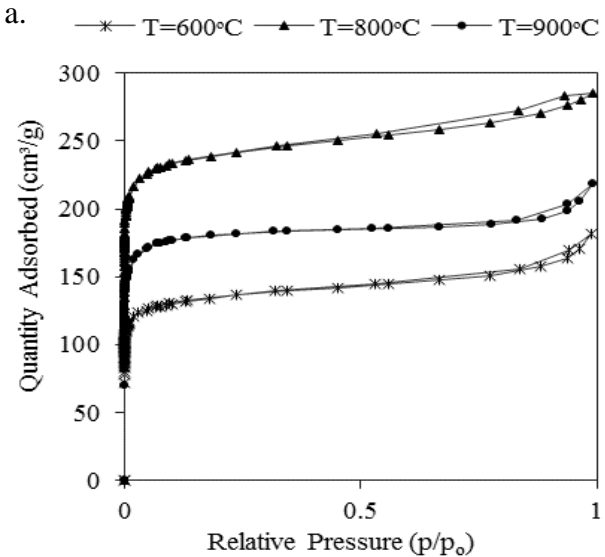

b.

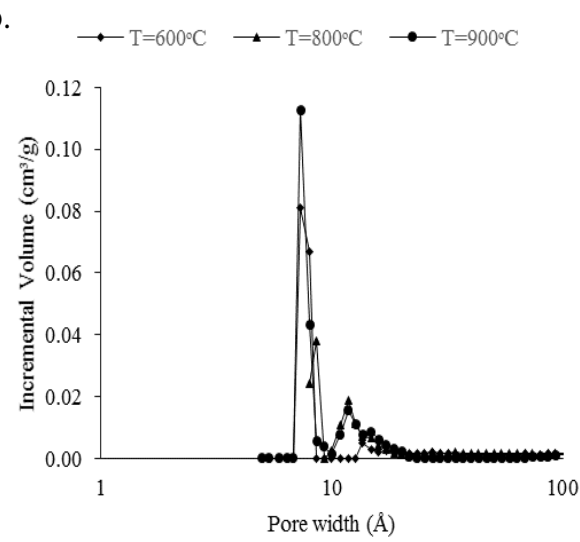

Figure 5. Nitrogen adsorption-desorption isotherms (a) and pore-size distributions (b) of carbon aerogel at variation of pyrolysis temperature. 
Table 2. Properties of carbon aerogel at variation in pyrolysis conditions.

\begin{tabular}{|l|c|c|c|c|}
\hline \multicolumn{1}{|c|}{ Temperature $\left({ }^{\circ} \mathbf{C}\right)$} & $\mathbf{6 0 0}$ & $\mathbf{7 0 0}$ & $\mathbf{8 0 0}$ & $\mathbf{9 0 0}$ \\
\hline Properties & 0.489 & 0.578 & 0.482 & 0.477 \\
\hline Density $\left(\mathrm{g} / \mathrm{cm}^{3}\right)$ & 61.5 & 52.6 & 68.2 & 62.4 \\
\hline Porosity $(\%)$ & 467.15 & 800.83 & 779.06 & 698.34 \\
\hline $\mathrm{S}_{\mathrm{BET}}\left(\mathrm{m}^{2} / \mathrm{g}\right)$ & 22.6 & - & 22.2 & 18.2 \\
\hline Average pore size $(\AA)$ & 6.5 & - & 6.1 & 6.5 \\
\hline Median pore width $(\AA)$ & 128.4 & - & 77.0 & 85.9 \\
\hline Average particle size $(\AA)$ & 0.2815 & - & 0.4408 & 0.3377 \\
\hline $\mathrm{V}_{\text {total }}\left(\mathrm{cm}^{3} / \mathrm{g}\right)$ & 0.1637 & - & 0.3173 & 0.2332 \\
\hline $\mathrm{V}_{\text {mic }}\left(\mathrm{cm}^{3} / \mathrm{g}\right)$ & 0.0663 & - & 0.0546 & 0.0371 \\
\hline $\mathrm{V}_{\text {mes }}\left(\mathrm{cm}^{3} / \mathrm{g}\right)$ & 0.0515 & - & 0.0689 & 0.0674 \\
\hline $\mathrm{V}_{\text {mac }}\left(\mathrm{cm}^{3} / \mathrm{g}\right)$ & 58.1 & - & 72.0 & 69.1 \\
\hline $\mathrm{V}_{\text {mic }}(\%)$ & 23.6 & - & 12.4 & 11.0 \\
\hline $\mathrm{V}_{\text {mes }}(\%)$ & 18.3 & - & 15.6 & 19.9 \\
\hline $\mathrm{V}_{\text {mac }}(\%)$ & & & & \\
\hline
\end{tabular}

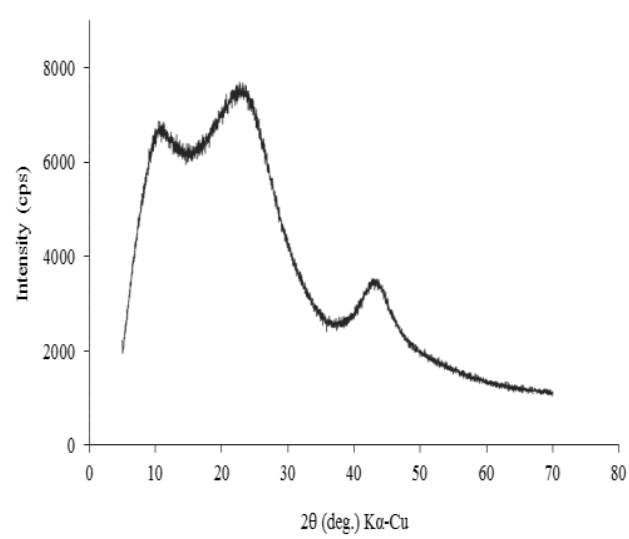

Figure 6. X-Ray diffraction pattern of carbon aerogel

The XRD diagram of the synthesized carbon aerogel samples were shown in Figure 6. It was found that carbon aerogel structure presented two large peaks at about $2 \theta=24^{\circ}$ and $44^{\circ}$, similar to the diffraction peaks of $\mathrm{C}(002)$ and $\mathrm{C}(101)$ and it was in agreement with the study of Rejitha et al. [4]. The first peak indicated that carbon aerogel contained a proportion of highly disordered materials in the form of amorphous carbon. In addition, the samples also contained some graphite-like structures indicated by the presence of a clear (002) band at $\sim 24^{\circ}$ and (101) weak band at $\sim 44^{\circ}$. These observations suggested that the crystallites in all the carbon aerogel samples have intermediate structures between graphite and amorphous state. 
Moreover, the presence of a peak at $\sim 10^{\circ}$ showed that the impurities were contained in the structure of carbon aerogel samples after pyrolysis. This peak was disappeared after activation process. The activation also improved the properties of carbon aerogel $[14,15]$.

\section{CONCLUSIONS}

Carbon aerogel was synthesized at different pyrolysis conditions and it indicated that carbon aerogel samples had highest specific surface area at pyrolysis temperature of $700^{\circ} \mathrm{C}$, with surface area value of $800 \mathrm{~m}^{2} / \mathrm{g}$. When increasing the pyrolysis temperature above $700^{\circ} \mathrm{C}$ the surface area was slightly decreased. The electrical conductivity of carbon aerogel was optimal at pyrolysis temperature of $800-900^{\circ} \mathrm{C}$. The pore-size was distributed in range of microporous with the average pore-size of 18-22 $\AA$. The total pore volume of carbon aerogel was in the range of 0.18 to $0.44 \mathrm{~cm}^{3} / \mathrm{g}$. The structure of carbon aerogel was characterized by XRD methods indicated that carbon aerogel had structure between amorphous and graphite state.

Acknowledgment: This research is funded by Academy of Military Science and Technology, Vietnam.

\section{Tính chất của carbon aerogel ở các điều kiện nhiệt phân khác nhau}

- Lê Khắc Duyên

- Phạm Quốc Nghiệp

- Lê Anh Kiên

Viện Nhiệt đới môi trường, ITE

\section{TÓM TẮT}

Carbon aerogel được tổng hợp bằng phản úng nhiệt phân các aerogel hưu co: Các yếu tố ảnh hương đến tính chất của carbon aerogel nhu khối luợng riêng, diện tích bề mặt riêng, độ dẫn điện trong quá trình nhiệt phân được khảo sát và đánh giá. Tính chất và cấu trúc của carbon aerogel được xác định bằng các phuơng pháp phân tích hóa lý nhu hấp phụ nitrogen, phuoong pháp 4 mũi dò, phuoong pháp XRD. Kết quả khảo sát cho thấy carbon aerogel có cấu trúc vô định hình kết hợp với một phần cấu trúc graphite. Diện tích bề mặt riêng đạt giá trị 800 $\mathrm{m} 2 / \mathrm{g}$ trong điều kiện nhiệt phân ở $700^{\circ} \mathrm{C}$. Cấu trúc lố xốp dạng micro với tổng thể tích lỗ xốp $0.44 \mathrm{~cm} 3 / \mathrm{g}$. Khả năng dẫn điện của carbon aerogel đat giá trị caol.744-1.923 S/cm trong khoảng nhiệt độ nhiệt phân 800-900 C.

Tù khóa: Aerogel, carbon aerogel, nhiệt phân, vật liệu xốp, cấu trúc micro. 


\section{REFERENCES}

[1]. A. Du, B. Zhou, Z. Zhang, and J. Shen, "A Special Material or a New State of Matter: A Review and Reconsideration of the Aerogel," Materials, vol. 6, pp. 941-968, 2013.

[2]. A. S. Dorcheh and M. H. Abbasi, "Silica aerogel; synthesis, properties and characterization," Journal of Materials Processing Technology, vol. 199, pp. 1026, 2008.

[3]. S. A. Al-Muhtaseb and J. A. Ritter, "Preparation and properties of resorcinolformaldehyde organic and carbon gels," Advanced Materials, vol. 15, pp. 101-114, 2003.

[4]. K. S. Rejitha, P. A. Abraham, N. P. Panicker, K. S. Jacob, and N. C. Pramanik, "Role of catalyst on the formation of resorcinol-furfural based carbon aerogels and its physical properties," 2013.

[5]. M. M. Koebel, N. Leventis, and M. A. Aegerter, Aerogels Handbook. New York: Springer Science \& Business Media, 2011.

[6]. J. Li, X. Wang, Y. Wang, Q. Huang, C. Dai, S. Gamboa, et al., "Structure and electrochemical properties of carbon aerogels synthesized at ambient temperatures as supercapacitors," Journal of Non-Crystalline Solids, vol. 354, pp. 1924, 2008.

[7]. Y. J. Lee, J. C. Jung, J. Yi, S.-H. Baeck, J. R. Yoon, and I. K. Song, "Preparation of carbon aerogel in ambient conditions for electrical double-layer capacitor," Current Applied Physics, vol. 10, pp. 682-686, 2010.

[8]. D. Wu, R. Fu, S. Zhang, M. S.Dresselhaus, and G. Dresselhaus, "Preparation of lowdensity carbon aerogels by ambient pressure drying," Carbon, vol. 42, pp. 2033-2039, 2004.
[9]. A. K. Le, D. Le, Q. N. Pham, and T. K. P. Le, "Synthesis of carbon aerogel material in atmosphere condition," Journal of Military Science and Technology Research, vol. 42, pp. 155-163, 2016.

[10].S. Kim, S. Hwang, and S. Hyun, "Preparation of carbon aerogel electrodes for supercapacitor and their electrochemical characteristics," Journal of materials science, vol. 40, pp. 725-731, 2005.

[11].R. Pekala, J. Farmer, C. Alviso, T. Tran, S. Mayer, J. Miller, et al., "Carbon aerogels for electrochemical applications," Journal of non-crystalline solids, vol. 225, pp. 7480, 1998.

[12].J. Rouquerol, F. Rouquerol, P. Llewellyn, G. Maurin, and K. S. Sing, Adsorption by powders and porous solids: principles, methodology and applications: Academic press, 2013.

[13].O. Czakkel, K. Marthi, E. Geissler, and K. László, "Influence of drying on the morphology of resorcinol-formaldehydebased carbon gels," Microporous and Mesoporous Materials, vol. 86, pp. 124133, 11/28/ 2005.

[14].T. Horikawa, J. i. Hayashi, and K. Muroyama, "Controllability of pore characteristics of resorcinol-formaldehyde carbon aerogel," Carbon, vol. 42, pp. 1625-1633, 2004.

[15].D. K. Kohli, R. Singh, A. Singh, S. Bhartiya, M. K. Singh, and P. K. Gupta, "Enhanced salt-adsorption capacity of ambient pressure dried carbon aerogel activated by $\mathrm{CO}_{2}$ for capacitive deionization application," Desalination and Water Treatment, pp. 1-7, 2014. 